\title{
Pengaruh Model Pembelajaran Berbasis Masalah Terhadap Hasil Belajar Mahasiswa
}

\author{
Ismail Hanif Batubara ${ }^{1}$, Putri Maisarah Ammy ${ }^{2}$ \\ ${ }^{1,2}$ Program Studi Pendidikan Matematika Universitas Muhammadiyah Sumatera Utara \\ E-mail: ismailhanif@ umsu.ac.id, 085370552283
}

\begin{abstract}
ABSTRAK
Tujuan dari penelitian ini adalah untuk mengetahui: (1) Apakah peningkatan hasil belajar matematik mahasiswa melalui model pembelajaran berbasis masalah lebih tinggi daripada peningkatan hasil belajar matematik mahasiswa yang tidak memperoleh model pembelajaran berbasis masalah, (2) Bagaimanakah interaksi antara pembelajaran dengan kemampuan awal matematik mahasiswa terhadap peningkatan hasil belajar mahasiswa. Penelitian ini merupakan penelitian quasi eksperimen. Populasi dari penelitian ini adalah seluruh kelas prodi pendidikan matematika semester lima yang berjumlah kurang lebih 184 orang. Secara acak, dipilih dua kelas dari enam kelas. Kelas eksperimen diberi perlakuan model pembelajaran berbasis masalah dan kelas control tidak diberi perlakuan pembelajaran berbasis masalah. Instrumen yang digunakan adalah tes uraian.. Analisis data dilakukan dengan analisis varians (ANAVA) dua jalur. Hasil penelitian menunjukkan (1) peningkatan hasil belajar mahasiswa melalui model pembelajaran berbasis masalah lebih tinggi daripada peningkatan hasil belajar pada mahasiswa yang tidak diberi perlakuan (kelas kontrol). (2) Tidak terdapat interaksi antara pembelajaran dengan kemampuan awal mahasiswa terhadap kemampuan peningkatan hasil belajar mahasiswa.
\end{abstract}

Kata Kunci : Model Pembelajaran Berbasis Masalah; Hasil belajar

\begin{abstract}
This research is aimed to know: (1) Whether the increasing of mathematical learning result of student through problem-based learning model is higher than the improvement of mathematical learning result of students who do not get problem based learning model (2) How the interaction between learning and early math ability of student mathematical learning result. This study was a quasi-experimental study. The population of this study is the entire class of five semester mathematics education study which amounted to approximately 184 people. Randomly, two classes were selected from six classes. The experimental class is treated with problem-based learning model and control class is not given problem-based learning treatment. The instrument used is a description test. The data analysis is done by analysis of two-way variance (ANAVA). The results showed (1) improvement of student learning outcomes through problem-based learning model is higher than the increase of learning outcomes in students who are not treated problem-based learning model (control class). (2) There is no Interaction between learning and early math ability of student mathematical learning result.
\end{abstract}

Keywords: Problem Based Learning Model ; Learning Result

\section{PENDAHULUAN}

Kemampuan menyusun perencanaan pembelajaran dan melaksanakan pembelajaran merupakan bagian dari kompetensi pedagogik guru yang harus dimiliki oleh guru untuk bisa melakukan pembelajaran yang mendidik sebagai persyaratan guru profesional. Perencanaan program sistem pengajaran berfungsi untuk memberikan arah pelaksanaan pembelajaran sehingga menjadi terarah dan efisien. Kegiatan-kegiatan dalam melaksanakan fungsi perencanaan diantaranya meliputi memperkirakan tuntutan dan kebutuhan, menentukan tujuan, 
menulis silabus kegiatan pembelajaran, menentukan topik-topik yang akan dipelajari, mengalokasikan waktu, serta menentukan sumber-sumber yang diperlukan.

UU N0. 14 Tahun 2005 Bab IV Pasal 20 (a) tentang Guru dan Dosen menyatakan bahwa standar prestasi kerja guru dalam melaksanakan tugas keprofesionalannya, guru berkewajiban merencanakan, melaksanakan proses pembelajaran yang bermutu serta menilai dan mengevaluasi hasil pembelajaran hasil pembelajaran. Dari pendapat di atas dapat diambil kesimpulan seorang guru profesional harus mampu merencanakan pembelajaran yaitu menyusun sendiri silabus program tahunan, program semester dan RPP.

Penerapan model pembelajaran Berbasis Masalah (PBL) merupakan salah satu metode dari banyaknya permasalahan - permasalahan yang muncul dalam sebuah pembelajaran . Model PBL ini sangat baik digunakan karena hal ini dapat membantu mengembangkan daya kreativitas dan meningkatkan kemampuan berpikir mahasiswa, membantu meningkatkan kerja sama antar mahasiswa melalui investigasi yang mereka lakukan sehingga pemahaman siswa terhadap pembelajaran matematika dapat meningkat khususnya pada mata kuliah pengembangan silabus pembelajaran matematika.

Istilah Pembelajaran Berbasis Masalah (PBM) di adopsi dari istilah Inggris Problem Based Instruction (PBI). Model pembelajaran berbasis masalah ini telah dikenal sejak zaman John Dewey (Trianto, 2011: 91). Model PBM atau Problem Based Instruction (PBI) juga dikenal dengan nama lain seperti Project Based Teaching (Pembelajaran Proyek), Experience Based Instruction (Pembelajaran Berdasarkan Pengalaman), Authentic Learning (Belajar Autentik), dan Anchored Instruction (pembelajaran bermakna atau berakar pada kehidupan).

Menurut Tan (Dalam Rusman, 2012 : 229) PBM merupakan inovasi dalam pembelajaran karena dalam PBM kemampuan berpikir siswa betul-betul dioptimalisasikan melalui proses kerja kelompok atau tim yang sistematis, sehingga siswa dapat memberdayakan, mengasah, menguji dan mengembangkan kemampuan berpikirnya. Dengan diterapkannya PBM ini maka hasil belajar mahasiswa akan lebih baik karena terstruktur dan sistematik. Batubara, IH (2017 : 49) menjelaskan bahwa model PBM sangat membantu mengembangkan daya kreativitas dan meningkatkan kemampuan berpikir siswa melalui investigasi yang mereka lakukan sehingga pemahaman konsep siswa terhadap pembelajaran matematika dapat meningkat.

Hasil belajar adalah kemampuan-kemampuan yang dimiliki mahasiswa setelah menerima pengalaman belajarnya, sedangkan menurut Gagne hasil belajar harus harus didasarkan pada pengamatan tingkah laku melalui stimulus respon (Sudjana, 2005:19). Hasil belajar berkenaan dengan kemampuan siswa di dalam memahami materi perkuliahan. Menurut Hamalik (2007: 31) mengemukakan, "hasil belajar pola-pola perbuatan, nilai-nilai, pengertianpengertian, sikap-sikap, apresiasi, ablititas dan keterampilan”.Sedangkan menurut Wahyuni (2012: 24) Hasil belajar matematika siswa juga diartikan sebagai hasil yang diperoleh siswa setelah menyelesaikan suatu paket belajar tertentu, yang dapat dicapai dalam berbagai bentuk melalui proses evaluasi.

Berpedoman pada UU di atas sesuai dengan profil lulusan program studi pendidikan matematika UMSU, dinyatakan bahwa lulusan sarjana pendidikan matematika harus mampu menjadi pendidik dan mendidik serta melakukan pembelajaran matematika tingkat pendidikan dasar dan menengah. Dengan kata lain, lulusan sarjana pendidikan matematika harus mampu menyusun silabus lanjutan serta mendesain silabus sesuai dengan prinsip-prinsip 
pengembangan silabus. Pentingnya hal tersebut berbanding terbalik dengan keadaan mahasiswa yang sudah duduk di semester atas. Banyaknya mahasiswa yang tidak menguasai prinsip-prinsip dalam pengembangan silabus serta membuat silabus lanjutan, banyaknya mahasiswa yang bingung dalam menentukan indikator dan tujuan pembelajaran, serta kebiasaan-kebiasaan yang sering terjadi dalam membuat dan mengembangkan silabus serta silabus lanjutan seperti model pembelajaran, media pembelajaran, evaluasi dan sebagainya menjadi hal yang urgen untuk diselesaikan.

Banyak faktor yang menjadi penyebab ketidakmampuan mahasiswa tersebut dalam mengembangkan silabus serta silabus lanjutan. Salah satunya adalah ketidaktepatan dan kurang bervariasi dalam penggunaan model pembelajaran dan media pembelajaran yang digunakan oleh pendidik di kelas. Kemudian mengenai Motivasi siswa itu sendiri. Menurut Omrod (dalam Saragi dan Suryani, 2018: 61) Motivasi adalah sesuatu yang menghidupkan (energize), mengarahkan, dan mempertahankan perilaku sehingga membuat siswa bergerak, menempatkan siswa dalam suatu arah tertentu, dan menjaga siswa agar terus bergerak". Selain itu pembelajaran matematika di kelas belum bermakna, bersusun dan tidak menekankan pada pemahaman siswa, sehingga pengertian mahasiswa tentang konsep sangat lemah. Untuk mengantisipasi masalah di atas, Pendidik dituntut mencari dan menemukan suatu cara yang dapat menumbuhkan motivasi belajar peserta didik. Pengertian ini mengandung makna bahwa pendidik diharapkan dapat mengembangkan suatu model pembelajaran yang dapat meningkatkan hasil belajar mahasiswa, mengembangkan, menyelidiki dan mengungkapkan ide peserta didik sendiri.

Tujuan penelitian ini adalah untuk mengetahui apakah peningkatan hasil belajar mahasiswa pada mata kuliah Pengembangan silabus pembelajaran matematika setelah mendapatkan pembelajaran dengan model pembelajaran berbasis masalah lebih tinggi dibandingkan dengan kelas yang tidak mendapatkan model pembelajaran serta mengetahui interaksi antara pembelajaran dengan kemampuan awal matematik mahasiswa terhadap peningkatan hasil belajar mahasiswa.

\section{METODE}

Populasi dari penelitian ini adalah seluruh kelas prodi pendidikan matematika semester lima yang berjumlah kurang lebih 184 orang. Sedangkan yang menjadi sampel pada penelitian ini adalah dua kelas yang dipilih dari kelas yang sudah ada pada prodi pendidikan matematika semester empat Fakultas Keguruan dan Ilmu Pendidikan Universitas Muhammadiyah Sumatera Utara tahun ajaran 2017/2018.

Penelitian ini merupakan penelitian quasi eksperiment. Penelitian ini dilakukan dengan model pembelajaran berbasis masalah. Secara garis besar disimpulkan bahwa penelitian ini dilaksanakan dengan tahapan : (1) Tahap penyusunan perangkat pembelajaran dan instrument penelitian yang meliputi tes awal dan sebagainya (2) Tahap pelaksanaan eksperimen berupa pemberian perlakuan pembelajaran, dan (3) Tahap analisis hasil penelitian. Setiap tahapan didesain sedemikian sehingga diperoleh data yang valid sesuai dengan karakteristik variabel dan tujuan penelitian. Data yang akan dikumpulkan dalam penelitian ini adalah data yang berkaitan dengan hasil belajar mahasiswa yang diambil menggunakan test. Tes dilakukan 
dengan memberikan soal-soal uraian (essay). Tes yang diberikan berupa soal pretest dan soal posttest.

Pengolahan data diawali dengan menguji persyaratan statistik yang diperlukan sebagai dasar dalam pengujian hipotesis, antara lain adalah uji normalitas data dan uji homogenitas varians. Selanjutnya, dilakukan uji- t, regresi dan korelasi yang disesuaikan dengan permasalahannya. Seluruh perhitungan statistik pada penelitian ini menggunakan bantuan program komputer SPSS 16.

Hipotesis 1 : Untuk menguji peningkatan hasil belajar mahasiswa

$\mathrm{H}_{0}: \mu_{x}=\mu_{y}$

$\mathrm{H}_{\mathrm{a}}: \mu_{x} \neq \mu_{y}$

Keterangan:

$\mu_{x}$ : Peningkatan hasil belajar mahasiswa yang diajarkan dengan model pembelajaran berbasis masalah.

$\mu_{y}$ : Peningkatan hasil belajar mahasiswa yang tidak diajarkan dengan model pembelajaran berbasis masalah (Konvensional).

Untuk menguji hipotesis ini digunakan rumus uji t dengan bantuan SPSS 16 dengan kriteria pengujiannnya adalah tolak $\mathrm{H}_{0}$ jika $t_{\text {tabel }}<t_{\text {hitung }}$ dan terima $\mathrm{H}_{0}$ untuk kondisi lainnya dengan taraf signifikansi yang telah ditentukan.

Hipotesis 2: Untuk menguji interaksi antara pembelajaran dan kemampuan awal matematik mahasiswa terhadap peningkatan hasil belajar mahasiswa.

$\mathrm{H}_{0}: \mu_{11}-\mu_{12}=\mu_{21}-\mu_{22}=\mu_{31}-\mu_{32}$

$\mathrm{H}_{\mathrm{a}}$ : Sedikitnya ada satu selisih rata-rata hasil belajar mahasiswa yang berbeda dari yang lainnya

Keterangan:

$\mu_{11}$ : Kelompok tinggi kemampuan awal matematik mahasiswa yang diajarkan dengan model pembelajaran berbasis masalah untuk peningkatan hasil belajar mahasiswa

$\mu_{12}$ : Kelompok tinggi kemampuan awal matematik mahasiswa yang diajarkan dengan tanpa model pembelajaran berbasis masalah (Konvensional) untuk peningkatan hasil belajar mahasiswa

Untuk menguji hipotesis 2 digunakan uji statistik anava dua jalur dengan menggunakan program SPSS 16.0. Kriteria pengujiannya adalah terima $\mathrm{H}_{0}$ jika nilai signifikansi (sig) lebih besar dari 0,05 dalam hal lainnya jika nilai signifikansi (sig) lebih kecil dari 0,05 $\mathrm{H}_{0}$ ditolak.

\section{HASIL DAN PEMBAHASAN}

\section{Deskripsi $\mathrm{N}$-gain Hasil Belajar Mahasiswa di Kelas Eksperimen dan Kelas Kontrol Tabel 1. N-gain Hasil Belajar Mahasiswa Pada Kedua Kelas Sampel}




\begin{tabular}{|c|c|c|c|c|}
\hline Kelas & $X_{\text {maks }}$ & $X_{\min }$ & $X_{\text {rata-rata }}$ & SD \\
\hline Eksperimen & 1.00 & 0.20 & 0.66 & 0.27 \\
\hline Kontrol & 1.00 & 0.17 & 0.49 & 0.25 \\
\hline
\end{tabular}

Agar lebih jelas perbedaannya maka digambarkan dalam diagram batang pada tabel 1 berikut ini.

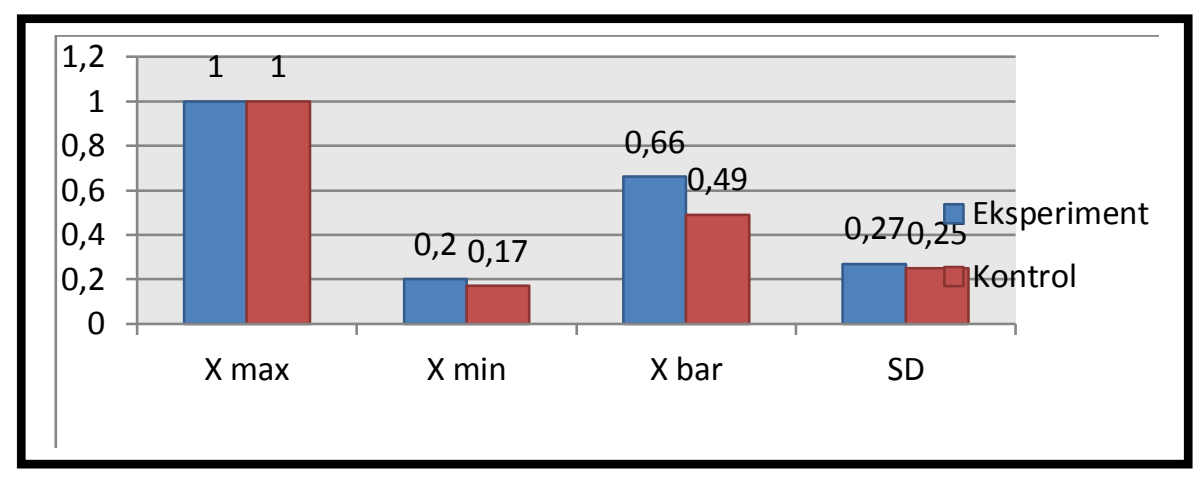

\section{Gambar 1. Diagram Batang $N$-gain Hasil Belajar Kelas Eksperimen dan Kontrol}

Pada Tabel 1 dan gambar 1 di atas terlihat bahwa nilai tertinggi $N$-gain pada kedua kelas sebesar 1. Sedangkan untuk nilai rata-rata $N$-gain kelas eksperimen sebesar 0,66 dan kelas kontrol sebesar 0,49. Jadi rata-rata $N$-gain kelas eksperimen lebih tinggi sedikit dibandingkan rata-rata $\mathrm{N}$-gain dikelas kontrol. Dari perolehan ini maka selisih rata-rata $\mathrm{N}$-gain antara kelas ekperimen dan kelas kontrol sebesar 0,17. Begitu juga dengan nilai standar deviasi untuk kelas eksperiment dan control memiliki selisih yang sangat tipis yakni sebesar 0, 02 .

\section{Uji Normalitas pada $N$-gain Kedua Kelas}

Hipotesis yang diuji untuk mengetahui normalitas kelompok data $\mathrm{N}$-gain kemampuan pemahaman konsep matematik adalah:

$\mathrm{H}_{0} \quad: \mathrm{f}(\mathrm{x})=$ normal

$\mathrm{H}_{\mathrm{a}} \quad: \mathrm{f}(\mathrm{x}) \neq$ normal

Tabel 2 .Tabel Normalitas $N$-gain Kedua Kelas

Tests of Normality

\begin{tabular}{|l|r|r|r|r|r|r|}
\hline & \multicolumn{4}{|c|}{ Kolmogorov-Smirnova $^{\mathrm{a}}$} & \multicolumn{3}{c|}{ Shapiro-Wilk } \\
\cline { 2 - 7 } & Statistic & \multicolumn{1}{|c|}{$\mathrm{df}$} & \multicolumn{1}{c|}{ Sig. } & Statistic & \multicolumn{1}{c|}{ df } & \multicolumn{1}{c|}{ Sig. } \\
\hline Eksperiment & .126 & 40 & .112 & .926 & 40 & .012 \\
Kontrol & .125 & 40 & .116 & .935 & 40 & .023 \\
\hline
\end{tabular}

a. Lilliefors Significance Correction

Dari hasil uji Kolmogorov-Smirnov test tersebut, diketahui bahwa nilai Signifikansi kelas eksperimen sebesar 0.112 sedangkan kelas kontrol sebesar 0.116. Karena nilai signifikansi kelas eksperimen $(0.112)>\alpha(0,05)$ sehingga data $N$-gain kelas eksperimen berdistribusi 
normal, dan untuk kelas kontrol nilai sig $>\alpha(0.116>0,05)$, artinya data $N$-gain kelas kontrol juga berdistribusi normal. Jadi data $N$-gain kelas eksperimen dan kelas kontrol berasal dari data berdistribusi normal. Dengan demikian data $\mathrm{N}$-gain kemampuan pemahaman konsep secara keseluruhan dapat disimpulkan berdistribusi Normal.

\section{Uji Homogenitas pada $N$-gain Hasil Belajar}

Setalah melalui tahap uji normalitas, data $N$-gain juga harus melalui tahap uji Homogenitas. Pada penelitian ini uji homogenitas menggunakan uji F. Hipotesis yang diuji untuk mengetahui homogenitas kelompok data $\mathrm{N}$-gain hasil belajar adalah:

$\mathrm{H}_{0} \quad: \sigma_{1}^{2}=\sigma_{2}^{2}$

$\mathrm{H}_{\mathrm{a}} \quad: \sigma_{1}^{2} \neq \sigma_{2}^{2}$

Keterangan:

$\sigma_{1}^{2}$ adalah varians skor kelompok model pembelajaran berbasis masalah

$\sigma_{2}^{2}$ adalah varians skor kelompok kelas control.

Tabel 3. Tabel Hasil Uji Homogenitas $N$-gain Kedua Kelas

\begin{tabular}{|c|c|c|c|}
\hline Test of & nogenei & Varianc & \\
\hline Levene Statistic & $\mathrm{df1}$ & $\mathrm{df2}$ & Sig. \\
\hline .186 & 1 & 78 & .668 \\
\hline
\end{tabular}

Dari hasil levene menggunakan program SPSS 22 tersebut, diketahui bahwa untuk pengujian homogenitas dengan uji Levene nilai sig $>\alpha(0.668>0,05)$ dan F hitung sehingga hipotesis nol diterima yang berarti semua populasi mempunyai varians yang sama/homogen. Dengan demikian data $\mathrm{N}$-gain kedua kelas secara keseluruhan dapat disimpulkan memliki varians yang sama atau homogen.

Berdasarkan pengujian Normalitas dan homogenitas di atas disimpulkan bahwa data $\mathrm{N}$ gain hasil belajar kedua kelas berdistribusi normal dan memiliki varians yang sama / homogeny

\section{Uji Hipotesis Pertama}

Dari hasil uji prasyarat analisis yakni uji normalitas dan homogenitas menunjukkan bahwa data $N$-gain mahasiswa berdistribusi normal dan varians dari setiap kelompok data sama, maka untuk menganalisisnya menggunakan uji statistik parametrik yakni menggunakan uji t dengan hipotesis statistik yang harus diuji untuk hasil belajar dirumuskan sebagai berikut:

$\mathrm{H}_{0}: \mu_{x}=\mu_{y}$

$\mathrm{H}_{\mathrm{a}}: \mu_{x} \neq \mu_{y}$

Keterangan:

$\mu_{x}$ : Peningkatan hasil belajar matematis mahasiswa kelas eksperiment

$\mu_{y}$ : Peningkatan hasil belajar matematis mahasiswa kelas kontrol

Berikut ini diperlihatkan hasil uji t $N$-gain kedua kelas sampel menggunakan SPSS 22: 
Tabel 4. Hasil Uji t Peningkatan Hasil Belajar Mahasiswa

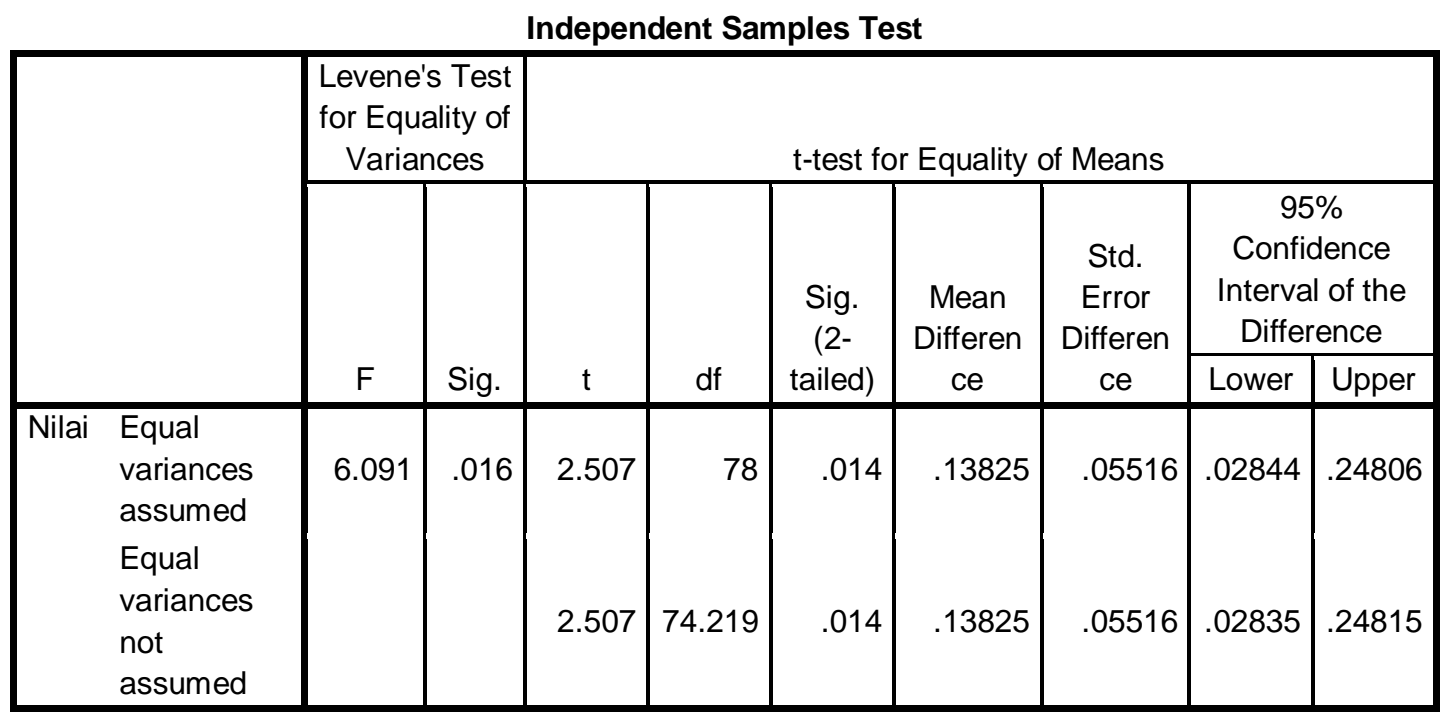

Berdasarkan hasil perhitungan pada tabel 4 di atas dengan menggunakan uji t pada

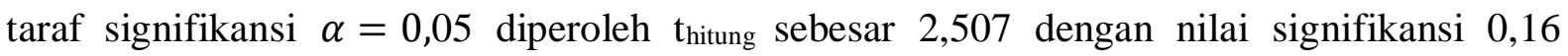
sedangkan $t_{\text {tabel }}$ sebesar 1,99 . Karena $t_{\text {hitung }}(2,507)>t_{\text {tabel }}(1,99)$ dan nilai signifikansi $(0,014)$ $<\alpha(0,05)$, sehingga $\mathrm{H}_{0}$ ditolak. Maka dapat disimpulkan bahwa peningkatan hasil belajar mahasiswa yang diajarkan melalui model pembelajaran berbasis masalah lebih tinggi dari pada yang tidak menggunakan metode pembelajaran (kelas control).

\section{Uji Hipotesis Kedua}

Hipotesis yang diajukan untuk di uji dengan uji ANAVA dirumuskan sebagai berikut:

$\mathrm{H}_{0}: \mu_{11}-\mu_{12}=\mu_{21}-\mu_{22}=\mu_{31}-\mu_{32}$

$\mathrm{H}_{\mathrm{a}}$ : Sedikitnya ada satu selisih rata-rata hasil belajar mahasiswa yang berbeda dari yang lainnya

Keterangan:

$\mu_{11}$ : Kelompok rendah kemampuan awal matematika siswa yang diajarkan dengan model pembelajaran berbasis masalah untuk meningkatan hasil belajar matematis mahasiswa

$\mu_{12}$ : Kelompok rendah kemampuan awal matematika siswa yang diajarkan dengan model pembelajaran berbasis masalah untuk meningkatan hasil belajar matematis mahasiswa

Kriteria pengujiannya adalah jika nilai significance (sig) lebih besar dari $\alpha=0,05$,

Maka $\mathrm{H}_{0}$ diterima, dalam hal lainnya di tolak.

Tabel 5. Hasil Uji Anava Berdasarkan Pembelajaran dan Kategori KAM 
Dependent Variable: GAIN

\begin{tabular}{|l|r|r|r|r|r|}
\hline Source & $\begin{array}{c}\text { Type III Sum of } \\
\text { Squares }\end{array}$ & df & Mean Square & F & Sig. \\
\hline Corrected Model & $.578^{\mathrm{a}}$ & 5 & .116 & 1.235 & .301 \\
Intercept & 15.682 & 1 & 15.682 & 167.546 & .000 \\
KELAS & .037 & 1 & .037 & .394 & .532 \\
KEMAMPUAN & .267 & 2 & .133 & 1.426 & .247 \\
KELAS * KEMAMPUAN & .183 & 2 & .091 & .976 & .381 \\
Error & 6.926 & 74 & .094 & & \\
Total & 27.565 & 80 & & & \\
Corrected Total & 7.505 & 79 & & & \\
\hline
\end{tabular}

a. R Squared $=.077$ (Adjusted R Squared $=.015$ )

Dari tabel 5 terlihat bahwa untuk faktor pembelajaran dan KAM, diperoleh nilai signifikansi sebesar 0,381. Karena nilai signifikansi lebih besar dari nilai taraf signikan 0,05, maka Ho diterima, yang berarti tidak terdapat interaksi antara model pembelajaran dengan kemampuan awal siswa terhadap peningkatan hasil belajar mahasiswa siswa. Jadi, peningkatan hasil belajar mahasiswa disebabkan oleh perbedaan pembelajaran yang digunakan bukan karena kemampuan awal matematika siswa. Dengan kata lain, tidak terdapat pengaruh secara bersama yang diberikan oleh pembelajaran dan KAM.

\section{PEMBAHASAN}

Melihat hasil penelitian yang telah dikemukakan di atas, menunjukkan bahwa model pembelajaran berbasis masalah secara signifikan lebih baik dalam meningkatkan hasil belajar siswa dibandingkan dengan tanpa menggunakan model pembelajaran sama sekali. Dalam kegiatan pembelajaran ini mahasiswa berkesempatan berinteraksi dengan komunitasnya. Mahasiswa akan saling berbagi ide untuk mengajukan penyelesaian baik di dalam kelompok maupun menyajikan hasil akhirnya di depan kelas. Sehingga mahasiswa dengan mudah dapat menemukan kesalahan-kesalahan pada penyelesaian masalah yang dibuat. Sedangkan bagi mahasiswa berkemampuan tinggi mempunyai kesempatan untuk berlatih menyampaikan ide dan gagasan kepada orang lain dan menghargai pendapat orang lain sehingga sangat memungkinkan dapat menambah pengetahuan mereka.

Namun pada kelas control kenyataan yang terjadi tidaklah seperti yang diharapkan. Sebagian besar mahasiswa tidak berupaya maksimum menggunakan segenap kemampuan kognisinya, dan tidak berinteraksi dengan komunitasnya dan mementingkan ego masingmasing. Sehingga mahasiswa bekerja secara individual pada saat menyelesaikan soal. Disamping mahasiswa mementingkan ego masing-masing , mahasiswa lainnya bergantung pada dosen dalam menyelesaikan soal, sehingga sifat pengulangan meniru dan menghafal sebagai pembentukan pengetahuan dengan dosen sebagai model dan sumber belajar juga terjadi di kelas ini. Dengan demikian, peran aktif mahasiswa serta interaksi yang terjadi sangat minim sekali.

Hal yang membuat tidak terdapat interaksi antara pembelajaran dengan tingkat kemampuan awal matematika mahasiswa terhadap peningkatan hasil belajar mahasiswa adalah 
faktor pemberian pembelajaran yang relatif sama antar kedua kelas. Sehingga kemampuan awal matematik siswa tidak memberi pengaruh secara bersamaan terhadap peningkatan hasil belajar mahasiswa.

Berdasarkan temuan di atas dapat disimpulkan bahwa penggunaan model Pembelajaran Berbasis Masalah lebih baik dibandingkan dengan model pembelajaran konvensional. Hasil temuan ini sejalan dengan penelitian yang dilakukan oleh Sugandi, A. (2013:154) yang menyatakan bahwa Kemandirian siswa dengan Pembelajaran Berbasis Masalah lebih baik daripada kemandirian siswa yang mendapat pembelajaran konvensional. Hasil temuan tersebut juga sesuai dengan temuan Batubara, IH (2017 : 103) yang menyatakan bahwa Peningkatan kemampuan berpikir kritis matematik siswa yang diajarkan melalui pembelajaran berbasis masalah berbantuan autograph lebih tinggi dari pada yang diajarkan melalui pembelajaran berbasis masalah berbantuan geogebra dan kelas konvensional.

\section{SIMPULAN}

Berdasarkan hasil analsis data di atas diperoleh beberapa kesimpulan yang merupakan jawaban atas petanyaan-pertanyaan pada rumusan masalah, diataranya:

1. Peningkatan hasil belajar mahasiswa yang diajarkan melalui pembelajaran berbasis masalah lebih tinggi dari pada peningkatan hasil belajar yang diajarkan dengan metode konvensional

2. Tidak terdapat interaksi antara model pembelajaran dengan kemampuan awal mahasiswa terhadap peningkatan hasil belajar mahasiswa.

3. Untuk meningkatkan hasil belajar mahasiswa, pendidik dapat menggunakan model pembelajaran berbasis masalah sebagai salah satu alternative.

4. Pendidik diharapkan perlu menambah wawasan tentang teori-teori pembelajaran yang lain (pembelajaran yang inovatif), dan dapat menerapkannya dalam pembelajaran.

5. Dalam setiap pembelajaran pendidik harus menciptakan suasana belajar yang memberi kesempatan kepada mahasiswa untuk mengungkapkan gagasan-gagasan matematika dalam bahasa dan cara mereka sendiri, sehingga dalam belajar matematika mahasiswa menjadi berani berargumentasi, lebih percaya diri, dan kreatif. 


\section{DAFTAR PUSTAKA}

Batubara, IH. (2017). "Peningkatan Kemampuan Pemahaman Konsep Matematis Melalui Model Pembelajaran Berbasis Masalah Berbantuan Autograph Dan Geogebra Di Sma Freemethodist Medan. Journal of Mathematics Education and Science. Vol (3) 4754.,Retrieved from https://jurnal.uisu.ac.id/index.php/mesuisu/article/view/219 $\rightarrow$ Jurnal online

Batubara, IH. (2017). "Peningkatan Kemampuan Berpikir Kritis Matematis Melalui Model Pembelajaran Berbasis Masalah Berbantuan Autograph Dan Geogebra Di Sma Freemethodist Medan, Kumpulan Jurnal Dosen Universitas Muhammadiyah Sumatera Utara, $\quad V(6), \quad 97-104 . \quad$ Retrieved from http://jurnal.umsu.ac.id/index.php/kumpulandosen/article/view/1368 $\rightarrow$ Jurnal online

Hamalik, Oemar. ((2010). Kurikulum Dan Pembelajaran. Jakarta: Bumi Aksara.

Rusman, dkk. (2011). Pembelajaran Berbasis Teknologi Informasi Dan Komunikasi. Jakarta : Raja Grafindo Persada.

Saragi, MPD, Suryani, Rina. (2018). "Perbedaan Perbedaan Motivasi Belajar Siswa Berjenis Kelamin Perempuan Dan Laki-Laki SMK Swasta Bandung". Jurnal Penelitian Bimbingan Konseling. Vol. 3 No. 1 60-68,. Retrived From http://jurnal.untirta.ac.id/index.php/JPBK/article/view/3197/2437. $\rightarrow$ Jurnal Online

Sudjana, N. (2005). Penilaian Hasil Proses Belajar Mengajar. Bandung : Remaja Rosdakarya.

Sugandi, A.I. (2013). Pengaruh Pembelajaran Berbasis Masalah Dengan Setting Kooperatif Jigsaw Terhadap Kemandirian Belajar Siswa SMA. Jurnal Ilmiah Program Studi 
Matematika STKIP Siliwangi Bandung, Vol (2) No (2), 144-155. Retrieved from https://doi.org/10.22460/infinity.v2i2.31.

Trianto. (2011). Mendesain Model-Model Pembelajaran Inovatif-Progresif, Konsep, Landasan, Dan Implementasinya Pada Kurikulum Tingkat Satuan Pendidikan (KTSP). Cetakan ke 4, Jakarta : Kencana.

Wahyuni, S. (2012). Perbedaan Hasil Belajar Matematika Siswa dengan Menggunakan Strategi Student Led Review Session dengan Metode Konvensional di SMP Muhammadiyah 57 Medan. FKIP UMSU. 